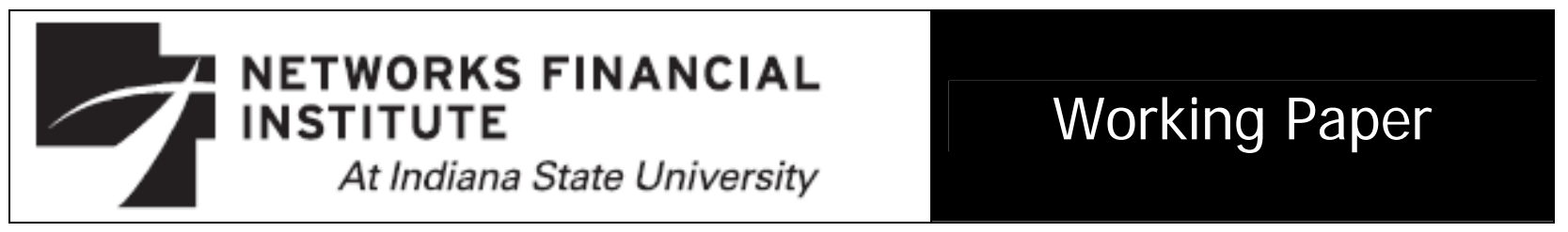

2008-WP-02

March 2008

Gender and Marital Differences in Wealth and I nvestment Decisions: I mplications for Researchers, Financial Professionals, and Educators Angela Lyons, Urvi Neelakantan, and Erik Scherpf

Abstract: Wealth is an important source of financial well-being and investment is an important vehicle to accumulate wealth. A large body of literature has focused on analyzing the systematic differences in wealth and investment behavior across gender and marital states. This paper provides a broad overview of the extant research and its implications for researchers, financial professionals, and educators.

About the Authors: Angela Lyons is an Assistant Professor in Department of Agricultural and Consumer Economics at University of Illinois at Urbana-Champaign.

Urvi Neelakantan is an Assistant Professor in Department of Agricultural and Consumer Economics at University of Illinois at Urbana-Champaign

Erik Scherpf is a Research Associate in Department of Agricultural and Consumer Economics at University of Illinois at Urbana-Champaign

Keywords: Wealth, investments, risk tolerance, portfolio allocation, household bargaining, financial education.

JEL Classification: D13, D14, J1, G11.

The views expressed are those of the individual author and do not necessarily reflect official positions of Networks Financial Institute. Please address questions regarding content to Angela Lyons at anglyons@illinois.edu. Any errors or omissions are the responsibility of the author.

NFI working papers and other publications are available on NFI's website (www. networksfinancialinstitute.org). Click "Research" and then "Publications/Papers." 


\section{Gender and Marital Differences in Wealth and I nvestment Decisions: I mplications for Researchers, Financial Professionals, and Educators}

Angela Lyons, Urvi Neelakantan, and Erik Scherpf

\section{Introduction}

Recent economic trends, like the growing prevalence of defined contribution retirement plans, have meant that individuals and households are becoming increasingly responsible for their own financial security. Financial security greatly depends on the ability to accumulate adequate wealth (Wolff, 1998). Wealth can be used to provide a direct service to consumers in the form of housing. As a liquid asset, it can be used to satisfy consumption needs. When held as emergency funds, it can help individuals and households better cope with unexpected life events. Perhaps most importantly, it can be a significant source of retirement income for individuals and families who are less and less able to rely on Social Security alone.

One source of concern, especially in today’s economic climate, is the persistent gap in wealth between men and women. Women's wealth has historically been lower than men’s for several reasons, including legal limits on women’s property rights and inheritance laws (Deere \& Doss, 2006). As these laws have changed, the gap between men's and women's wealth has narrowed. However, the difference continues to be significant even after controlling for individual characteristics (Schmidt \& Sevak, 2006). In 2001, the mean non-pension wealth was $\$ 119,861$ for single males and $\$ 112,547$ for single females. Another source of concern is the difference in wealth between singles and married persons. Married couples hold substantially higher wealth than single persons, even after controlling for the presence of two earners in a married household (Díaz-Giménez, Quadrini, \& Ríos-Rull, 1997; Schmidt \& Sevak, 2006). In particular, retirement wealth has differed significantly across gender and marital states. Among full-time workers approaching retirement age with pension coverage, men had $76 \%$ greater 
pension wealth than women (Johnson, Sambamoorthi, \& Crystal, 1999). Approximately onethird of this gender difference could not be accounted for even after controlling for education, demographics, and job characteristics. Among married persons aged 51 to 61 in 1992, women's mean pension wealth was only one-fourth the size of men's mean pension wealth (Gustman, Mitchell, Samwick, \& Steinmeier, 1997).

These trends raise several important questions from a financial planning perspective. Are the investment and wealth management practices of women significantly different from those of men? Can differences in risk tolerance account for disparities in wealth across gender and marital states? How does control over wealth affect bargaining power within the household, and how does bargaining power in turn affect financial planning decisions? A growing body of literature attempts to address these questions. The research on risk tolerance finds that women are more risk averse than men, though the evidence is far from conclusive. The literature also finds that women tend to invest their retirement assets more conservatively than men. Finally, the dynamics of intra-household bargaining within marriage appear to have a significant influence on household financial decisions.

In this paper, we do not attempt an exhaustive review of the large literature that addresses these questions. Instead, we focus on providing a broad overview. The answers to these questions can have important implications for the financial well-being of consumers, particularly women, and can provide valuable insights to financial planning professionals and educators. For example, previous research has found that people may invest too conservatively due to a lack of financial experience or expertise (Haliassos \& Bertaut, 1995). Overly conservative investments can lead to low levels of wealth accumulation and may account for the gender gap in wealth. Thus, findings from this research can be used to help financial professionals provide more 
targeted financial education to consumers. We discuss these implications and provide some directions for future research.

Our review is organized as follows. In the next two sections, we look at whether risk tolerance differs by gender and compare the investment decisions of men and women. We then look at the impact of marriage on financial decisions and how intra-household bargaining affects those decisions. In the final sections, we summarize the central themes from the literature and present directions for future research. We also discuss implications for financial professionals and educators.

\section{Gender and Risk Tolerance}

It is a widespread belief that women are more risk averse than men in making financial decisions. This belief can have critical implications for the financial well-being of women (Schubert, Brown, Gysler, \& Brachinger, 1999). For example, women may be passed over for promotion in the corporate world based on the perception that they are unable to make required risky financial decisions (Johnson \& Powell, 1994). Financial advisers, believing that women are more risk-averse, may recommend conservative portfolios that have lower returns (Wang, 1994). It is therefore crucial to understand whether women are indeed more risk averse than men. This question has been studied within several disciplines.

Within the personal finance literature, some papers have used self-reported responses to hypothetical scenarios to measure risk tolerance and to assess whether it varies by gender. For example, the Survey of Consumer Finances (SCF) asks the following question: "Which of the following statements on this page comes closest to the amount of financial risk that you are willing to take when you save or make investments?” The possible responses are: (1) take substantial financial risks expecting to earn substantial returns (2) take above average financial 
risks expecting to earn above average returns, (3) take average financial risks expecting to earn average returns, and (4) not willing to take any financial risks. Grable and Lytton (1998) and Sung and Hanna (1996) analyzed the responses to this question and concluded that women were significantly less risk tolerant than men. This result was supported by Grable (2000), who used a 20-item instrument to assess risk-tolerance among faculty and staff at a university. Hallahan, Faff, and McKenzie (2004), using a psychometric risk tolerance score (RTS), also found that women had lower risk tolerance than men. However, in a survey of university students with two subjective measures of risk tolerance—one of which was similar to the SCF question—Hanna, Gutter, and Fan (2001) found no significant correlation between gender and risk aversion.

This research raises the question of whether self-reported risk tolerance is a good measure of actual risk tolerance. Hallahan et al. (2004) compared their RTS with self-assessed risk tolerance. While the two generally matched, they found that respondents tended to underestimate their risk tolerance. This result suggests that financial advisors should be careful when using subjective measures of risk tolerance, because these may lead them to make portfolio recommendations that are too conservative.

Researchers have also made inferences about women's risk tolerance based on observed wealth accumulation and investment choices (Dwyer, Gilkenson, \& List 2002; Jianakoplos \& Bernasek 1998). In economic theory, absolute risk aversion and relative risk aversion are common measures of risk tolerance (Arrow, 1971; Pratt, 1964). ${ }^{1}$ It is widely accepted that absolute risk aversion decreases with wealth. This implies that more of the risky asset is purchased as wealth increases. However, there is still some debate over the relationship between

\footnotetext{
${ }^{1}$ Absolute risk aversion is defined as $-\frac{U^{\prime \prime}(W)}{U^{\prime}(W)}$ and relative risk aversion as $-W \frac{U^{\prime \prime}(W)}{U^{\prime}(W)}$ where $U$ is the utility function and $W$ is wealth.
} 
wealth and relative risk aversion. Thus, it is not clear if the proportion of wealth invested in the risky asset increases, decreases, or remains constant as wealth increases. Using SCF data, Jianakoplos and Bernasek (1998) found that as individuals' wealth increased, the proportion of wealth held in risky assets increased for both men and women, but the effect was significantly smaller for single women than for single men and married couples. They concluded that single women were more risk averse than single men and married couples. Note, however, that observed differences in investment decisions may not be the result of risk tolerance alone. In a survey of mutual fund investors, Dwyer et al. (2002) found that women took less risk than men in their mutual fund investment decisions. However, the impact of gender on risk-taking was reduced significantly when they controlled for the investor's financial knowledge. This result is key from the personal finance perspective because it suggests that rather than recommending more conservative portfolios to women, financial advisors should focus on reducing knowledge disparities between men and women.

Psychological research on this topic may shed some light on the findings from the economic and finance literature. Studies using simulations of risky situations like military decision problems (Hudgens \& Fatkin, 1985) and gambling (Levin, Synder, \& Chapman, 1988) have shown that women are indeed more cautious than men. However, there is some debate about whether gender differences in task familiarity drive these results. Levin et al. (1988) pointed out that differences in observed behavior may be the result of gender-specific orientation. This is particularly important for financial decisions, and the results from the literature are mixed. For example, in surveys of college students at a large state university, Goldsmith and Goldsmith (1997) and Goldsmith, Goldsmith, and Heaney (1997) found that men reported higher levels of financial knowledge than women. This supports the findings of Dwyer 
et al. (2002) reported earlier. One way to control for financial knowledge and skills is to survey persons from the same profession. Webster and Ellis (1996) surveyed professional business analysts and university professors in accounting and found that men were more self-confident than women in performing financial analysis. However, the most important question is whether gender differences in preferences and behavior affect performance. Powell and Ansic (1997) found that while women chose different strategies from men in financial decision-making, the strategies had no significant impact on their ability to perform financial analysis.

To summarize, the above research highlights three key points. First, risk tolerance should be measured with care, since measurement errors may lead to inappropriate financial recommendations. Second, while men and women do differ in their observed investment choices, the reasons for the differences may go beyond risk tolerance, and may include knowledge and psychological factors as well. Finally, it is important to look not just at differences in preferences and behavior, but also at whether there are resulting differences in outcomes. In the next section, we look more closely at gender differences in investment behavior and outcomes.

\section{Gender and Investment Decisions}

Much of the research on gender and investment decisions has focused on comparing asset allocations within retirement plans (Bernasek \& Shwiff, 2001; Hinz, McCarthy, \& Turner, 1997; Papke, 1988 Sundén \& Surette, 1998). This is particularly important given the movement towards self-managed plans. With the exception of Papke (1988), these studies have shown that women invest their retirement assets more conservatively than men.

Bernasek and Shwiff (2001) collected detailed information on household decisionmaking from faculty members employed at five universities in Colorado. They used the data to investigate the effect of gender on the riskiness of an individual's defined contribution plan 
(DCP). They found that women invested a significantly lower percentage of their pension in stocks.

Hinz et al. (1997) used data from federal workers in a government-sponsored Thrift Savings Plan to examine gender differences in the allocation of their plans to common stock, fixed income funds, and Treasury securities. They found that $28 \%$ of women participated in the common equity fund compared to $45 \%$ of men. Furthermore, of those who participated, only $8.9 \%$ of women's funds were allocated to the equity fund compared to $15.3 \%$ of men's funds. Papke (1998) used the National Longitudinal Survey (NLS) of mature women, which asked whether respondents had invested their DCP in mostly stocks, mostly interest-bearing assets, or a split between the two. In contrast to other work, she found no effect of gender on investment choices. Instead, she found that people who were able to choose their investments put 14 percentage points more in stocks than people with no choice.

Sunden and Surette (1998) used the SCF, which, like the NLS, reported whether the DCP was invested in mostly stocks, mostly bonds, or a diversified portfolio. They found that gender (and marital status) affected ownership and allocation of a DCP. In particular, single women were more likely than single men to have a DCP while married women were the least likely to have a DCP. Single women and married men were less likely than single men to invest their DCP in mostly stocks.

If women's investment choices are different from men's, what might be the reasons? Sunden and Surette (1998) found that demographics, financial characteristics, and attitudes were important controls, but that these did not fully explain differences across marital states and gender. Moreover, they interpreted their results as descriptive rather than causal. 
Within the literature that looks for causal explanations, there has been some support for the view that differences in investment choices are indeed the result of risk tolerance. For example, Bajtelsmit, Bernasek, and Jianakoplos (1999) found that gender differences in relative risk aversion led to single women allocating smaller amounts to their DCP. Confidence may also play a role. As we have seen earlier, psychological research has shown that men tend to be more overconfident than women in areas like finance. Theory predicts that overconfident people trade excessively. Barber and Odean (2001) tested this prediction using account data from a discount brokerage firm and found that men traded $45 \%$ more than women. Trading reduced men's net returns by 2.65 percentage points a year compared to 1.72 percentage points for women, suggesting that gender differences affect not just behavior but also outcomes.

\section{Marriage and Financial Decision-Making}

In addition to the large body of research that has examined differences in risk aversion and investment decisions between men and women, a number of studies have also looked at the role that gender plays in the financial decision-making of married couples (e.g., Bernasek \& Bajtelsmit, 2002; Bernasek \& Shwiff, 2001; Dobbelsteen \& Kooreman, 1997; Jianakoplos, Bajtelsmit, \& Bernasek, 2003; Lyons \& Yilmazer, 2007; Sundén \& Surette, 1998; Uccello, 2000; Woolley, 2003; Zagorsky, 2003). These studies show that married individuals generally do not make investment decisions on their own. Rather, their investment choices tend to be influenced by their spouse, either because their spouse acts as the household decision-maker in financial matters or because the couple makes joint financial decisions, possibly as an outcome of intrahousehold bargaining.

These studies have largely focused on the way married couples allocate assets in their financial portfolios, with particular emphasis on retirement savings accounts. The asset mix that 
households choose — whether mostly stocks, bonds, or evenly split—is used to gauge the individual's financial risk tolerance. Jianakoplos et al. (2003) examined whether spouses invest their DCPs similarly or whether they seek to share risk by diversifying their DCPs. They found that the investment choices of both spouses were more similar than different, suggesting either that one spouse was making decisions for the other spouse or that individuals tended to find partners with similar attitudes toward risk. Using similar analysis, Uccello (2000) also showed that spouses tend to choose similar asset mixes for their respective DCPs. One caveat to these findings, however, is that, even with the proliferation of DCPs, households in which both spouses own such a plan are not necessarily representative of married households as a whole.

Also, one of the empirical challenges in this line of research has been to tease out the true effect of gender on investment decisions for married individuals. The traditional approach has been to estimate a household wealth or asset allocation equation, using a dummy variable to capture the gender effect. Attributing a gender effect to this dummy variable assumes, however, that married individuals make financial decisions independent of their spouses—an assumption that has become less tenable in light of recent empirical evidence which suggests that the financial choices of married individuals also reflect, at least in part, the preferences of their spouse. In an effort to remove the influence of spouses on financial outcomes, some researchers have restricted their samples to include only singles. Another approach has been to compare the investment behavior of single women to that of other groups such as married couples or single men (e.g., Bajtelsmit \& Bernasek, 2001; Jianakoplos \& Bernasek, 1998).

Recognizing that the investment choices of married individuals may not be entirely their own, researchers have increasingly turned their attention to better understanding the decisionmaking process within married households. However, empirically testing models of household 
decision-making has been hampered by the lack of direct measures of how couples arrive at financial decisions. Consequently, most studies have relied on various proxy measures, such as differences in spouses' ages, education, and income, that are believed to reflect relative bargaining power within the household (i.e., relative control over the household's financial resources). Lyons and Yilmazer (2007) used differences in age, education, and income and found that married women with characteristics indicative of greater control over the financial resources than their husbands were less likely to invest their DCPs in risky assets. Moreover, women who were married to relatively older men were also less likely to take on financial risk. Interestingly, they found little evidence that the characteristics of married women affected the investment decisions of their husbands.

While the proxy measures used in studies such as Lyons and Yilmazer (2007) provide useful insights into the financial decision-making process of married households, they still represent imperfect measures of actual decision-making power. The Health and Retirement Study (HRS) is one of the few data sets that provides researchers with direct measures by asking married couples to identify: (1) which spouse is more financially knowledgeable, and (2) which spouse has the "final say" in making financial decisions for the household.

A number of recent studies have used the HRS data to examine both the sources and consequences of decision-making power (e.g., Elder \& Rudolph, 2003; Friedberg \& Webb, 2006; Lyons, Neelakantan, Fava, \& Scherpf, 2007). Elder and Rudolph (2003) employed the "final say" question in the HRS to identify the sources of decision-making power within households. They found that decisions were more likely to be made by the spouse with more financial knowledge, more education, and a higher wage, irrespective of gender. These results largely confirmed findings of studies that had relied on less direct measures of decision-making 
power. The authors did not explore, however, how the locus of decision-making responsibility in the household affected financial outcomes.

Friedberg and Webb (2006) used the HRS "final say" question to investigate both the determinants and consequences of decision-making power and its effect on household wealth and stock market investments. In their analysis, they pointed out that many of the variables used in earlier studies to explain the distribution of bargaining power may in fact be endogenous, as they may be correlated with unobservable factors that affect the outcome variable. They controlled for potential endogeneity by employing a two-stage method in which they first estimated ordered probit equations that determined the relative bargaining power for each spouse and then substituted the estimates of bargaining power into their wealth and investment equations. They found that households tended to invest more heavily in equities when husbands held more decision-making power. Their study also revealed interesting interactions between household decision-making power and the age of the primary decision-maker. For instance, when husbands had the final say in financial matters, household wealth was significantly higher when the husband was older. Likewise, when the wife had the final say, household wealth was significantly higher when the wife was older.

In yet another study, Lyons et al. (2007) used the HRS data on both the primary financial decision-maker and the more financially knowledgeable spouse to investigate how these sources of bargaining power affected various stages of the investment process (i.e., whether or not to acquire an individual retirement account (IRA), how much to invest in the IRA, and how to allocate assets in the IRA). They discovered that when the husband had more decision-making power, or the decision-making power was about equal, the couple was more likely to own an IRA and to invest more in the account than when the wife had more decision-making power. 
Furthermore, when the husband was identified as the more financially knowledgeable spouse, the couple was more likely to choose an asset allocation consisting of mostly stocks.

While the HRS is perhaps one of the best sources of household decision-making data, other data sources have also been used (e.g., Bernasek \& Shwiff, 2001; Dobbelsteen \& Kooreman, 1997; Woolley, 2003). Bernasek and Shwiff (2001) used their survey data from Colorado universities to examine how financial decision-making power and attitudes toward financial risk between spouses affected individuals' asset allocations in their DCPs. They found that spouses who were the primary decision-maker for the household invested their DCP in less risky portfolios. They also found that married women and men reacted in opposite ways to their partners' attitudes toward financial risk.

Two other studies used household decision-making data collected outside of the U.S. Woolley (2003) identified determinants of decision-making power for married households in Canada. She found that higher levels of male income and education were associated with greater male control over the household's finances. Likewise, female income was positively associated with specific types of financial decisions such as those related to cash withdrawals. Dobbelsteen and Kooreman (1997) used data from the British Household Panel Survey to investigate factors that affected each spouse's involvement in the management of the household's finances. Similar to the HRS, this survey asked married couples about "who [had] the final say in big financial decisions," in addition to asking which spouse was responsible for a number of other financial management tasks such as paying bills and household spending. More details on this study are presented in the next section.

Overall, recent work that utilizes direct controls for decision-making power has advanced our understanding of how households make decisions and how different management systems 
affect financial outcomes. However, even these studies have limitations. Couples often disagree about which spouse is the primary financial decision-maker or which spouse is more financially knowledgeable. Moreover, responses to these questions can depend on which spouse is being interviewed. For example, Zagorksy (2003) used NLS data from five cohorts, in which each spouse was interviewed separately, and found that husbands and wives provided substantially different reports of household income and finances. Husbands generally reported higher income and asset holdings than their wives, while wives tended to report more debt than their husbands. Zagorsky (2003) also noted that money ranked as one of the most contentious issues among married couples, evidence that financial decisions are likely the result of some type of bargaining. Using the HRS, Elder and Rudolph (2003) found that only 63.5\% of married couples were in agreement over who was primarily responsible for the household's financial decisions, raising questions about the reliability of self-reported measures of decision-making power. Lyons et al. (2007) similarly found that $36.6 \%$ of spouses disagreed about decision-making responsibility in the household.

Another limitation of this line of research has been that many of the studies seem to lack an adequate theoretical context or framework for supporting the empirical findings and explaining the financial decision-making process within a household. This is the focus of the next section.

\section{Marriage and Household Bargaining}

Theoretical models of family decision-making have been used extensively, especially within the economics and demography literature (see Bergstrom (1997), Dobbelsteen and Kooreman (1997), Elder and Rudolph (2003), and Vermeulen (2002) for a summary of the theories related to household decision-making behavior). Traditional models of household 
decision-making treat married households as single decision-making units (e.g., Becker, 1981). These unitary models assume that the husband and wife pool their resources and maximize a single household utility function, where allocation decisions are determined by an altruistic household head. These decisions are independent of how much each spouse contributes to the resource pool. Tastes and preferences of both spouses are assumed to be the same and exogenously determined.

Similarly, studies that have focused on gender and marital differences in wealth and investment decisions typically have treated married households as single decision-making units (e.g., Bajtelsmit et al., 1999; Jianakoplos \& Bernasek, 1998; Jianakoplos et al., 2003; Papke, 1998; Sundén \& Surette, 1998). However, as discussed in the previous section, exactly how financial decisions are made between spouses has been the subject of much debate. The empirical evidence has shown that the pooling of resources described by the unitary model does not occur. A household's financial decisions are based on relative control of resources in the household, and spouses may have different preferences, especially for risk tolerance, that can affect those decisions. For these reasons, researchers have moved away from using traditional unitary models and instead have turned to bargaining-based models to explain the decisionmaking process of married couples. Some researchers have empirically tested the assumptions of the unitary model versus the bargaining model. Elder and Rudolph (2003) specifically used the models to test how financial decisions are being made. They found that financial decisions are the product of a bargaining process in which the spouse with greater decision-making power and more financial knowledge has more influence over the household's financial decisions.

The bargaining framework allows spouses to have different preferences. Bargaining can be either noncooperative or cooperative (e.g., Lundberg \& Pollak, 1994, 1996). In the 
noncooperative framework, each spouse maximizes his or her own utility given the behavior of his/her partner. Spouses do not pool resources but can both contribute to one or more shared household goods. The noncooperative model has several Cournot-Nash equilibria, some of which may not be Pareto optimal. In other words, distribution of resources within the marriage may be inefficient.

In the cooperative bargaining model, husbands and wives work to resolve individual differences through Nash bargaining (Lundberg and Pollak, 1996). Researchers make one of two possible assumptions regarding the threat point in the cooperative model. Some assume that the threat point is the inefficient noncooperative outcome while others assume that the threat point is the level of utility each spouse would have outside of the marriage. The outcome of the cooperative bargaining depends on the threat point chosen. Husbands and wives do not necessarily pool their income. Their behavior is affected by the income controlled by each of them separately.

A growing number of studies have used cooperative bargaining theory to explain the financial decision-making process of married couples (e.g., who in the household is making the decisions and whether couples coordinate their investment decisions so as to pool their financial risk) (Browning, 2000; Lundberg, Startz, \& Stillman, 2001; Lundberg \& Ward-Batts, 2000; Lyons \& Yilmazer, 2007; Lyons, et al., 2007). These studies typically assume that the spouse who has more bargaining power will have more say in the financial decisions. Thus, control within the marriage depends less on who owns the resources in name and more on who has greater bargaining power. As a result, household financial decisions will tend to reflect more closely the preferences of the spouse with greater bargaining power. 
Some studies have investigated how joint decision-making affects household saving and consumption behavior, using differences in income, age, and education between spouses as proxies for bargaining power within the household (e.g., Browning, 2000; Lundberg, Startz, \& Stillman, 2001; Lundberg \& Ward-Batts, 2000). Browning (2000) constructed and tested a bargaining model that took into account differences in savings preferences between husbands and wives. He found that the level and amount of saving in the portfolio, as well as the time path of consumption, was dependent on the relative income and age of the two spouses. Lundberg and Ward-Batts (2000) estimated a bargaining model of household saving behavior and found that households where the husband had more education than the wife had lower levels of net worth. Lundberg, Startz, and Stillman (2003) used the bargaining framework to explain declines in household consumption around the age of retirement. Since bargaining power in the household depends on relative control over resources, the husband's retirement from a job may reduce his ability to influence consumption and saving decisions. They found that a decline in consumption for married couples was more pronounced for households in which the age difference between the husband and wife was larger.

Other studies have used cooperative bargaining theory to explain how married couples’ allocate assets to their financial portfolios. Lyons and Yilmazer (2007) used a cooperative bargaining model to examine how spouses' relative control over financial resources and lifecycle stage affects the allocation of assets in married men's and women's DCPs. Lyons et al. (2007) used the cooperative framework to examine how decision-making and bargaining power between spouses affects individual's ownership and allocations in IRAs. The findings for both of these studies were presented in the previous section. Both showed that couples do in fact engage 
in a bargaining process and that process can significantly affect the household's financial outcomes.

Another study by Dobbelsteen and Kooreman (1997) tested the bargaining model against a competing theory - the household production model - to see which would better explain the household decision-making process. The household production model assumes that couples allocate their time efficiently to market work, financial management, and leisure. The model predicts that the spouse with the lower (potential) market wage will take on the burden of financial management in the household while the other spouse will devote more time to market work. The bargaining model, on the other hand, predicts the opposite - that the spouse with the higher wage will primarily be responsible for financial decision-making, since wage differences are viewed as a source of bargaining power. The bargaining model was found to better explain the way households manage their finances than the production model, evidence that power considerations were more important than efficiency considerations.

\section{Directions for Future Research}

This paper has provided an overview of the literature related to gender and marital differences in wealth and investment decisions. While significant progress in the field has been made, there is still much work to be done. Throughout this review, we have attempted to highlight some of the gaps in the current literature so as to provide scholars with directions for future research. We summarize some of the most fruitful areas below.

First, there is a need for more rigorous, theory-based research on financial decisionmaking behavior. Stronger links need to be made between theory and empirical work so that the field of personal finance can develop a better understanding of how financial decisions are being made at the individual and household levels. Theory provides context, and a baseline, for what 
individuals and households should be doing in practice. There are numerous opportunities for researchers to test various theories to see if their predictions match real-world financial data. Those theories that pass the tests can then be used to make predictions about future financial behavior (Lyons and Neelakantan 2008). For example, researchers have applied bargaining theory to explain the wealth and portfolio allocation decisions of married couples. To date, most of the research has focused on using cooperative bargaining models. It might be interesting for researchers to consider a noncooperative framework where each spouse maximizes his or her own utility given the behavior of the other spouse and where there is no pooling of financial resources.

In addition to conducting more theory-based research, there is also a need for gathering more microlevel data on the household financial decision-making process. Specifically, the field of personal finance could benefit from more primary and secondary data sets that contain detailed information on: (1) which individuals are making the household's financial decisions, (2) what specific decisions they are making, and (3) how the household's financial tasks are being divided between spouses and among other family members. In addition, it is of interest to look at the impact that decision-making power has on the financial choices of individuals and households over time. The literature has established that men and women have different preferences and risk tolerance. However, almost all of these findings are based on cross-sectional data. It is possible that these differences might change over time, affecting bargaining power, and ultimately future allocations to financial portfolios. A longitudinal data set that is rich in financial and demographic information would help to provide insight into how the household decision-making process changes over time. 
Accurately identifying the primary financial decision-maker for each household is also an important issue for future research. Recent studies have begun to use information from the HRS to directly identify who in the household is more financially knowledgeable and who is primarily responsible for making the family decisions. This type of data provides opportunities to test whether direct measures of decision-making power provide information beyond traditional measures of bargaining power. Lyons et al. (2007) used both direct decision-making measures and traditional bargaining power measures. They found evidence to suggest that traditional bargaining measures, which are often observable in secondary data sets, may be adequate proxies for decision-making power. However, their results depended significantly on which measure of decision-making power was used.

Before a couple is interviewed in the HRS, the interviewer asks a series of questions to establish which spouse is more financially knowledge (according to an objective measure determined by HRS), and thus better able to respond to detailed financial questions in the survey. During the HRS interview, both spouses are asked to report who, in their opinion, is primarily responsible for making the family decisions (a subjective, self-reported measure). Lyons et al. (2007) found that the self-reported measure was not a particularly good predictor of the household's investment decisions. The objective measure was found to provide more meaningful and significant results as to the impact that decision-making power had on couples' investment decisions. Researchers are cautioned to think carefully when collecting self-reported measures on financial decision-making behavior, especially given that over one-third of married couples in the HRS disagreed about which spouse was the primary decision-maker.

Finally, several studies have focused on decision-making as it relates to investments in retirement plan accounts. However, this is only one component of an individual's overall 
financial portfolio. Also, many of these studies focus on a single type of retirement account (e.g., IRA or DCP), which may not provide a complete picture of how individuals and couples are making decisions for their retirement. Much of the existing research has been driven by available data. However, future research might want to take into consideration how decision-making affects investment choices in the household's complete portfolio rather than in particular accounts or assets.

Overall, there are numerous opportunities for researchers to further explore gender and marital differences in wealth and investment decisions. Researchers, students, financial professionals, and educators are encouraged to use this paper as a foundation to better understand the existing literature and to identify promising areas for future research.

\section{Implications for Financial Professionals and Educators}

Individuals and families are bearing greater responsibility for their own finances, particularly with the growth in self-managed retirement accounts. Given this trend, financial professionals and educators are playing an increasingly important role in helping people make appropriate financial choices. The body of literature we have reviewed provides some insights that can also help financial professionals and educators in this role, especially when they consider the diverse needs of men and women, and single and married individuals. The following is a summary of some of the lessons that can be gained from the literature.

The risk tolerance of the client is clearly an important factor in making investment recommendations. The literature sheds some light on how financial professionals and educators should interpret measures of risk tolerance, especially when working with women. Women may tend to understate their risk tolerance and their observed preference for more conservative investments may result from a lack of financial knowledge. Thus, before recommending overly 
conservative portfolios to women, there may be a need to better educate women about the riskreturn tradeoff and help them make more informed choices.

In addition, the literature suggests that there is a need for more specific and targeted financial education to help men and women with their investment decisions. Men may need to be cautioned about the pitfalls of trading excessively, which leads to a fall in investment returns. Women may need additional guidance on how to make investment choices that carry a certain amount of risk so that there is sufficient growth in their savings, particularly for retirement. Men and women who do not have choices within an employer-sponsored retirement plan may need more information on alternative investment options such as an IRA. This information could significantly enhance their retirement security.

Financial professionals and educators can also use the results from the household bargaining literature to better inform married couples about their financial options and the importance of not leaving the financial decisions entirely to one's spouse. The theoretical literature suggests that husbands and wives could achieve more efficient outcomes by cooperating in the financial planning process rather than by making independent choices.

In addition, financial professionals and educators can use the findings from the research to develop educational resources and services that take gender and marital differences in financial behaviors into consideration. Specifically, financial advisors could develop more tailored intake forms for their clients that identify not only the financial resources and services they need, but also how decisions are being made within the household and the characteristics of each spouse.

Finally, the findings from the literature can be used to evaluate the impact of policies that shift investment responsibilities to individuals, especially married couples. In recent years, there 
have been a number of proposed Social Security reforms that would enable individuals to choose how their personal security accounts are invested. In view of these legislative proposals, it is important that financial professionals and educators communicate to policymakers how the decision-making process within households can affect financial investments. The literature has shown decision-making power and couples' characteristics (e.g., the age gap) can significantly affect their retirement savings decisions. Some couples are likely to be at greater risk than others for being inadequately prepared for retirement. These factors should be taken into consideration when proposing Social Security reforms. 


\section{References}

Arrow K. J. (1971). The theory of risk aversion. In K. J. Arrow (Ed.), Essays in the Theory of Risk Bearing (pp. 90-133). Chicago, IL: Markham Publishing Company.

Bajtelsmit, V., \& Bernasek, A. (1996). Why do women invest differently than men? Financial Counseling and Planning, 7(1), 1-10.

Bajtelsmit, V., Bernasek, A., \& Jianakoplos, N. (1999). Gender differences in defined contribution pension decisions. Financial Services Review, 8(1), 1-10.

Barber, B. M., \& Odean, T. (2001). Boys will be boys: Gender, overconfidence and common stock investment. The Quarterly Journal of Economics, 116(1), 261-292.

Becker, G. (1981). A treatise on the family. Cambridge, MA: Harvard University Press.

Bergstrom, T. C. (1997). A survey of theories of the family. In M. Rosenzweig \& O. Stark (Eds.), Handbook of population and family economics (pp. 21-79). New York, NY: North-Holland.

Bernasek, A., \& Bajtelsmit, V. (2002). Predictors of women’s involvement in household financial decision-making. Financial Counseling and Planning, 13(2), 39-48.

Bernasek, A., \& Shwiff, S. (2001). Gender, risk, and retirement. Journal of Economic Issues, 35(2), 345-356.

Browning, M. (2000). The saving behavior of a two-person household. Scandinavian Journal of Economics, 102(2): 235-51.

Dobbelsteen, S., \& Kooreman, P. (1997). Financial management, bargaining and efficiency within the household: An empirical analysis. De Economist, 145(3), 345-366.

Deere, C. D. \& Doss, C. R. 2006. The gender asset gap: What do we know and why does it matter? Feminist Economics, 12(1), 1-50. 
Díaz-Giménez, J., Quadrini, V., \& Ríos-Rull, J-V. (1997). Dimensions of inequality: Facts on the U.S. distributions of earnings, income, and wealth. Federal Reserve Bank of Minneapolis Quarterly Review, 21(2), 3-21.

Dwyer, P. D., Gilkenson, J. H., \& List, J. A. (2002). Gender differences in revealed risk taking: Evidence from mutual fund investors. Economic Letters, 76(2), 151-58.

Elder, H. W., \& Rudolph, P. M. (2003). Who makes the financial decisions in the households of older Americans? Financial Services Review, 12(4), 293-308.

Friedberg, L., \& Webb, A. (2006). Determinants and consequences of bargaining power in households. (Working paper \#12367). Cambridge, MA: National Bureau of Economic Research.

Goldsmith, E. B., \& Goldsmith, R. E. (1997). Gender differences in perceived and real knowledge of financial investments. Psychological Reports, 80(11), 236-238.

Goldsmith, E. B., Goldsmith, R. E., \& Heaney, J.-G. (1997). Sex differences in financial knowledge: A replication and extension. Psychological Reports, 81, 1169-1170.

Grable, J. E. (2000). Financial risk tolerance and additional factors that affect risk taking in everyday money matters. Journal of Business and Psychology, 14(4), 625-630.

Grable, J. E. \& Lytton, R. H. (1998). Investor risk tolerance: Testing the efficacy of demographics as differentiating and classifying factors. Financial Counseling and Planning, 9(1), 61-74.

Gustman, A. L., Mitchell, O. S., Samwick, A. A., \& Steinmeier, T. L. (1997). Pension and social security wealth in the Health and Retirement Study. (NBER Working Paper No. 5912). Cambridge, MA: National Bureau of Economic Research. 
Hallahan, Terrence A., Robert W. Faff, and Michael D. McKenzie. (2004). An empirical investigation of personal financial risk tolerance. Financial Services Review, 13(1), 5778.

Haliassos, M., \& Bertaut, C. C. (1995). Why do so few hold stocks? Economic Journal, 105(432), 1110-1129.

Hanna, S. D., Gutter, M. S., \& Fan, J. X. (2001). A measure of risk tolerance based on economic theory. Financial Counseling and Planning, 12(2), 53-60.

Hinz, R., McCarthy, D., \& Turner, J. (1997). Are women conservative investors? Gender differences in participant-directed pension investments. In M. Gordon, O. Mitchell, \& M. Twinney (Eds.), Positioning pensions for the twenty-first century (pp. 91-103). Philadelphia, PA: University of Pennsylvania Press.

Hudgens, G. A., \& Fatkin, L. T. (1985). Sex differences in risk taking: Repeated sessions on a computer-simulated task. The Journal of Psychology, 119(3), 197-206.

Jianakoplos, N. A., Bajtelsmit, V. L., \& Bernasek, A. (2003). How marriage matters to pension investment decisions. Journal of Financial Services Professionals, 57(2), 48-57.

Jianakoplos, N. A., \& Bernasek, A. (1998). Are women more risk averse? Economic Inquiry, 36(4), 620-630.

Johnson, J. E. V., \& Powell, P. L. (1994). Decision making, risk and gender: Are managers different? British Journal of Management, 5(2), 123-138.

Johnson, R. W., Sambamoorthi, U., \& Crystal, S. (1999). Gender differences in pension wealth: Estimates using provider data. Gerontologist, 39(3), 320-333. 
Levin, I. P., Synder, M. A., \& Chapman, D. P. (1988). The interaction of experiential and situational factors and gender in a simulated risky decision-making task. The Journal of Psychology, 122(2), 173-181.

Lundberg, S. J., \& Pollak, R. A. (1996). Bargaining and distribution in marriage. Journal of Economic Perspectives, 10(4), 139-158.

Lundberg, S. J., \& Pollak, R. A. (1994). Noncooperative bargaining models of marriage. American Economic Review, 84(2), 132-37.

Lundberg, S. J., Startz, R., \& Stillman, S. (2003). The retirement-consumption puzzle: A marital bargaining approach. Journal of Public Economics, 87(5-6), 1199-1218.

Lundberg, S. J., \& Ward-Batts, J. (2000). Saving for retirement: Household bargaining and household net worth. (WP 2000-004). Ann Arbor, MI: Michigan Retirement Research Center, University of Michigan.

Lyons, A. C., \& Neelakantan, U. (in press). Potentials and pitfalls of applying theory to the practice of financial education. The Journal of Consumer Affairs, 42(1).

Lyons, A. C., Neelakantan, U., Fava, A., \& Scherpf, E. (2007). For better or worse: Financial decision-making behavior of married couples. (Working Paper 2007-WP-14). Indianapolis, IN: Networks Financial Institute, Indiana State University.

Lyons, A. C., \& Yilmazer, T. (2007). Marriage and the allocation of assets in women's defined contribution plans (Working paper). West Lafayette, IN, Purdue University.

Papke, L. (1988). How are participants investing their accounts in participant-directed individual account pension plans? American Economic Review, 88(2), 212-16.

Powell, M., \& Ansic, D. (1997). Gender differences in risk behavior in financial decisionmaking: An experimental analysis. Journal of Economic Psychology, 18(6), 605-628. 
Pratt, J. W. (1964). Risk aversion in the small and in the large. Econometrica, 32(1-2), 122-136.

Riley, W. B., \& Chow, K. V. (1992). Asset allocation and individual risk aversion. Financial Analysts Journal, November/December, 32-7.

Schubert, R., Brown, M., Gysler, M., \& Brachinger, H. W. (1999). Financial decision-making: Are women really more risk averse? The American Economic Review Papers and Proceedings, 89(2), 381-385.

Schmidt, Lucie \& Sevak, P. (2006). Gender, marriage, and asset accumulation in the United States. Feminist Economics, 12(1-2), 139-166.

Sundén, A. E., \& Surette, B. J. (1998). Gender differences in the allocation of assets in retirement savings plans. American Economic Review, 88(2), 207-211.

Sung, J., \& Hanna, S. (1996). Factors related to risk tolerance. Financial Counseling and Planning, 7, 11-20.

Uccello, C. E. (2000). Do spouses coordinate their investment decisions in order to share risks? (Working paper 2000-09). Chestnut Hill, MA: Center for Retirement Research: Boston College.

Vermeulen, F. (2002). Collective household models: Principles and main results. Journal of Economic Surveys, 16(4), 533-564.

Wang, P. (1994). Brokers still treat men better than women. Money, 23(6), 108-110.

Webster, R. L., \& Ellis, T. S. (1996). Men’s and women’s self-confidence in performing financial analysis. Psychological Reports, 79, 1251-1254.

Wolff, E. N. (1998). Recent trends in the size distribution of household wealth. The Journal of Economic Perspectives, 12(3), 131-150. 
Woolley, F. (2003). Control over money in marriage. In S. A. Grossbard-Shechtman (Ed.), Marriage and the economy, Theory and evidence from advanced industrial societies (pp. 105-128). New York, NY: Cambridge University Press.

Zagorsky, J. L. (2003). Husbands’ and wives’ view of the family finances. The Journal of SocioEconomics, 32(2), 127-146. 